\title{
POLA ASUH ORANG TUA DARI REMAJA DENGAN PERILAKU AGRESIF DI DESA GEGER KABUPATEN MADIUN
}

\author{
Lailatul Restu Suprihatin \\ Fakultas Ushuluddin Adab dan Dakwah IAIN Ponorogo \\ Lailatulrestu99@gmail.com \\ Mayrina Eka Prasetyo Budi \\ Fakultas Ushuluddin Adab dan Dakwah IAIN Ponorogo \\ mayrinaekapb@gmail.com
}

\begin{abstract}
This study aims to reveal the aggressive behavior of adolescents and various kinds of parenting styles in Geger Village. This research is qualitative with descriptive qualitative approach. The data collection technique was done by observing, interviewing and documenting. The data analysis technique is done by processing data, presenting data, and drawing conclusions. The validity or validity of the data is tested by triangulation techniques, including using the triangulation technique of data sources, methods, and theories. The results showed that from five subjects obtained several types of aggressive behavior. These types of aggressive behavior include directactive-verbal, direct-active-non-verbal, direct-passive-non-verbal aggressive behavior. There were also aggressive behaviors that differed from different parenting styles.
\end{abstract}

Keywords: parenting patterns, adolescent, aggressive behavior

\begin{abstract}
Abstrak
Penelitian ini bertujuan untuk mengungkap perilaku agresif remaja dan berbagai macam pola asuhnya di Desa Geger. Penelitian ini termasuk kualitatif dengan pendekatan kualitatif deskriptif. Teknik pengumpulan data dilakukan dengan observasi, wawancara, dan dokumentasi. Teknik analisis data dilakukan dengan mengolah data, penyajian data, dan penarikan kesimpulan. Keabsahan atau validitas data diuji dengan teknik triangulasi, diantaranya menggunakan teknik triangulasi sumber data, metode, dan teori. Hasil penelitian menunjukkan dari lima subjek didapatkan beberapa jenis perilaku agresif. Jenis perilaku agresif tersebut di antaranya adalah perilaku agresif langsung-aktif-verbal, langsung-aktif-non verbal, dan
\end{abstract}


langsung-pasif-non verbal. Ditemukan juga adanya perilaku agresif yang berbeda dari pola asuh yang berbeda.

\section{Kata Kunci: pola asuh, remaja, perilaku agresif}

\section{PENDAHULUAN}

Keluarga adalah tempat belajar pertama bagi seorang anak. Keluarga menjadi salah satu faktor penting dalam membentuk perilaku dan kepribadian seorang anak. Keluarga yaitu orang tua bertanggung jawab menanamkan kebaikan sedini mungkin. Gaya pengasuhan atau pola asuh orang tua sangat mempengaruhi anak di masa remaja. Baumrind menyatakan pola asuh adalah cara orangtua membesarkan anak dengan memenuhi kebutuhan anak, memberi perlindungan, mendidik anak, serta mempengaruhi tingkah laku anak dalam kehidupan sehari-hari. ${ }^{1}$ Pola asuh yang diterapkan akan menentukan remaja dalam berperilaku. Pola asuh yang kurang tepat akan menyebabkan remaja terlibat dalam berbagai perilaku negatif seperti perilaku agresif. Kasus remaja membunuh anak usia lima tahun yang terjadi di awal Maret menarik perhatian banyak orang dan lembaga. Remaja tersebut membunuh anak kecil karena terinspirasi dari film yang bernuansa kekerasan. Remaja tersebut termasuk anak yang jarang keluar rumah, dan lebih banyak di rumah menonton, sedangkan orang tuanya tidak memperhatikan media yang dikonsumsi anaknya. Terlihat bahwa pola yang diterapkan dalam mengasuh anaknya kurang tepat. ${ }^{2}$

Orang tua memiliki peran penting dalam membentuk perilaku dan kepribadian anak. Jika orang tua memberikan teladan dan pola asuh yang baik, maka anak akan tumbuh dan berkembang dengan baik. Hal tersebut sebagaimana ditemukan dalam berbagai penelitian. Anita salah satu Mahasiswi UIN Ar-Raniry dalam penelitiannya mengenai perilaku anak sesuai dengan apa yang diajarkan orang tuanya. Dari hasil penelitiannya terlihat bahwa anak meniru perilaku orang tuanya yang mengamalkan ajaran agama Islam. Dikatakan bahwa orang tua di daerah Gampong Beurawe Aceh ini

\footnotetext{
${ }^{1}$ Rahmatika Hamdani, "Pengaruh Tipe Pola Asuh Dan Penerimaan Sosial Terhadap Perilaku Merokok Pada Remaja Di Samarinda" Edukasi, 2 (Tb, 2019), 356.

2 Tio, "Siswi SMP Bunuh Bocah 5 Tahun, Diduga Karena Kelalaian Orang Tua" Kronologi, 9 Maret

2020, https://kronologi.id/2020/03/09/siswi-smp-bunuh-bocah-5-tahun diakses pada 17 Maret 2020
} 
mampu menciptakan suasana yang sejahtera, damai, dan bahagia. Mereka memberikan contoh perilaku yang bersifat positif. ${ }^{3}$

Penelitian serupa juga pernah dilakukan oleh Adristinindya Citra Nur Utami dan Santoso Tri Raharjo. Penelitian tersebut menyatakan bahwa keluarga menjadi salah satu faktor anak bersifat agresif dan menyimpang. Anak yang menjadi subyek dalam penelitian terungkap lebih dimanja oleh ibu dan diabaikan oleh ayahnya, sehingga anak tersebut terlibat pergaulan negatif sampai membunuh seseorang pada saat tawuran. ${ }^{4}$ Ada juga beberapa penelitian yang berkaitan dengan pola asuh beserta pengaruhnya. Pertama, penelitian Rahmatika Hamdani dengan judul "Pengaruh Tipe Pola Asuh dan Penerimaan Sosial Terhadap Perilaku Merokok Pada Remaja di Samarinda". Hasil penelitian menunjukkan $75 \%$ perilaku merokok dipengaruhi oleh pola asuh, di mana pola asuh permisif (Childern Centered) lebih dominan dalam mempengaruhi perilaku anak. Jenis pola asuh ini berpusat pada anak dan semua keputusan berada di tangan anak, sehingga orang tua terkesan membebask an. ${ }^{5}$

Kedua, jurnal yang ditulis Erni Agustina Setiowati, dkk, dengan judul "Gambaran Agresivitas Anak dan Remaja di Area Beresiko" mengatakan bahwa keluarga berperan terhadap perilaku buruk pada anak. Pengasuhan yang tidak konsisten dan kedekatan keluarga yang tidak aman (insecure attachment) lebih beresiko. Pengasuhan tersebut menumbulkan masalah perilaku anak pra sekolah seperti permusuhan, melawan, dan menyimpang. Hubungan kedekatan yang tidak aman juga merupakan prediktor agresivitas pada siswa sekolah dasar perempuan. Selain dari faktor keluarga, beberapa faktor yang dinilai berkontribusi terhadap perkembangan perilaku agresif pada anak yakni kontrol diri dan regulasi emosi. Regulasi emosi merupakan aspek spesifik dari kontrol diri yang berpengaruh terhadap perkembangan

\footnotetext{
${ }^{3}$ Anita Sastriani, Keharmonisan Keluarga dan Pengaruhnya Terhadap Pengamalan Agama Anak di Gampong Beurawe Aceh, Skripsi: 2018, 91.

${ }^{4}$ Adristinindya Citra Nur Utami dan Santoso Tri Raharjo, "Pola Asuh Orang Tua Dan Kenakalan Remaja" Pekerjaan Sosial, 1 (Juli, 2019), 151.

${ }^{5}$ Rahmatika Hamdani, "Pengaruh Tipe Pola Asuh Dan Penerimaan Sosial Terhadap Perilaku Merokok Pada Remaja Di Samarinda” Edukasi, 2 (Tb, 2019), 360.
} 
conduct disorder (gangguan perilaku). Faktor yang selanjutnya yakni relasi dengan teman sebaya yang memiliki keterkaitan erat dengan perilaku agresif. ${ }^{6}$

Ketiga, penelitian M. Munawir yang di tampilkan pada Prosiding Seminar ASEAN, dengan judul "Dampak Perbedaan Pola Asuh Terhadap Perilaku Agresif Remaja di SMA Peraya". Menurut Munawwir, pola asuh orang tua memiliki pengaruh yang signifikan terhadap perilaku agresif. Pola asuh permisif dan pola asuh otoriter memiliki pengaruh yang positif terhadap perilaku agresifitas. Selain itu, anak yang mengalami kekecewaan, kurang kasih sayang dan kepedulian dari orang tuanya, membuat mereka lebih senang berada diluar rumah. Bahkan anak yang mengalami stres dan frustasi atas masalah yang dihadapinya tanpa diberi bantuan dan jalan keluar oleh orang tuanya lebih memilih jalan pintas untuk menyelesaikan masalahnya. Mereka melampiaskan dengan menggunakan narkoba, minum-minuman ber-alkohol sampai dengan melakukan perkelahian. ${ }^{7}$

Perilaku agresif remaja tidak hanya terjadi di satu daerah. Perilaku ini dijumpai di banyak daerah. Tidak hanya di kota, bahkan juga terjadi di desa. Berdasarkan hasil observasi awal dijumpai perilaku agresif di desa Geger Kabupaten Madiun. Agresif dalam bentuk fisik maupun non verbal. Salah satunya yaitu remaja yang berperilaku agresif terhadap kakek dan neneknya, termasuk dengan orang lain. Pernah terjadi adu mulut yang menyebabkan hilangnya komunikasi antara remaja tersebut dan tetangganya. Perilaku tersebut muncul akibat kurangnya pengasuhan dan perhatian dari orang tua. Ayahnya tidak diketahui keberadaannya. Ibunya memilih tinggal dengan suami barunya. Selama ini remaja tersebut tinggal bersama nenek dan kakek. Pola asuh sebagai salah satu faktor yang mempengaruhi perilaku agresif selalu menarik untuk diteliti. Penelitian ini berusaha menggali pola asuh dan perilaku agresif pada remaja di Desa Geger Kabupaten Madiun.

\footnotetext{
${ }^{6}$ Erni Agustina Setiowati, dkk, "Gambaran Agresivitas Anak dan Remaja di Area Beresiko" Edukasi, (Agustus, 2017), 173.

${ }^{7}$ M. Munawir, "Dampak perbedaan pola asuh terhadap perilaku agresif remaja di SMA Peraya" Prosiding Seminar ASEAN, (Februari, 2016), 260.
} 


\section{METODE PENELITIAN}

Penelitian ini menggunakan metode penelitian kualitatif deskriptif. Pengumpulan data dilakukan dengan menggunakan metode observasi, wawancara dan dokumentasi. Analisis data dilakukan dalam beberapa tahapan yaitu pengumpulan data dan organisasi data, mentranskrip data, membaca dan mempelajari data, memilah, menguraikan, serta menafsirkan data. Pengujian keabsahan data menggunakan teknik triangulasi sumber data, metode, dan teori.

\section{HASIL PENELITIAN DAN PEMBAHASAN}

\section{a. Perilaku remaja di Desa Geger}

Berdasarkan observasi dan wawancara diketahui para remaja di Desa Geger memiliki kegemaran berkumpul dengan teman sebayanya. Terlebih setelah menjamurnya warung khusus anak muda yang biasa disebut angkringan. Di angkringan, para remaja sering bermain game online bersama. Saat mereka mengalami kekalahan terdengar beberapa ungkapan yang tidak sopan (agresif dalam bentuk verbal). Salah satu remaja yang suka berkumpul dan menghabiskan waktu bersama teman-temannya adalah HD. Kondisi remaja Desa Geger yang suka berkumpul ini sesuai dengan teori perubahan psikis pada remaja yang menyatakan bahwa kegiatan berkumpul atau berkelompok merupakan suatu kegiatan yang sangat disukai oleh remaja. Kegiatan berkumpul dilakukan sebagai bentuk pencarian identitas diri pada remaja melalui kelompok sebayanya. Hal ini dapat dikatakan wajar mengingat insting untuk berkumpul adalah salah satu ciri dari perubahan psikis remaja sebelum memasuki usia dewasa. ${ }^{8}$

Perilaku agresif remaja ditujukan kepada teman saat berkumpul bersama. Tidak jarang perilaku agresif juga dilakukan kepada orang tuanya. Salah satu remaja yang memiliki perilaku demikian adalah RN. Informasi tentangga menceritakan bahwa ketika marah RN bersikap tidak sopan dan berperilaku agresif yaitu menghadapkan pantat ke orang tuanya, termasuk kepada kakek atau neneknya. Saat bersama orang lain RN bersikap tidak acuh. Kondisi tersebut juga peneliti lihat langsung ketika melakukan

\footnotetext{
${ }^{8}$ Tn, "Memahami Perubahan Fisik dan Psikis Remaja", https://ghurubhaz.wordpress.com/2018/05/01/memahami-perubahan-fisik-dan-psikis-remaja/ di akses pada 16 Mei 2020
} 
wawancara dengan tetangga RN. Saat melakukan wawancara, terdengar suara ibu RN memarahi anaknya karena RN mengumpat kepada ibunya. Dengan nada tinggi pula RN menjawab kalau ibunya juga sering mengumpat padanya. Berdasarkan hal ini terlihat bahwa perilaku agresif seorang anak muncul dikarenakan adanya perilaku yang sama dari orang tuanya. Anak akan mempelajari apa yang diberikan oleh orang tuanya. Perilaku agresif ini dapat dipahami melalui pendekatan belajar sosial. Teori ini menganggap perilaku agresif muncul dari adanya hasil belajar maupun mengalami secara langsung. Selain RN, ada juga HD yang memiliki perilaku yang kurang baik terhadap orang tuanya dan orang lain yang lebih tua. Hal tersebut dikarenakan HD lebih sering menghabiskan waktu bersama teman-temannya. Hal ini makin menguatkan bahwa periku remaja dipengaruhi oleh lingkungan pertemanan.

Remaja lain yang memiliki perilaku agresif adalah salah satu dari anggota karang taruna (AN). Perilaku AN ini menyebabkan adu mulut antara ia dengan teman (IR) atau kakak temannya. Pertengkaran terjadi dikarenakan AN tidak mau menghargai IR yang sedang menyampaikan pendapat di depan para remaja anggota karang taruna. Hal tersebut terjadi dikarenakan usia IR yang lebih muda dari AN. Selain dua remaja di atas terdapat remaja lain yang mengaku pernah melakukan perilaku kasar berupa membentak dan mengumpat teman ataupun orang tuanya. Ada sebagian remaja berperilaku agresif dikarenakan dalam keadaan sedang bad mood dan orang lain (teman atau orang tua) tidak memahami kondisi tersebut. Remaja lain berperilaku kasar dikarenakan mereka pernah menjadi korban dari teman-temannya. Remaja yang menjadi santri di pondok pesantren mengaku pernah berperilaku agresif, yaitu mengghosob sandal dan menyakiti temannya secara fisik maupun psikis. Mereka menyampaikan alasan berperilaku agresif disebabkan pernah diperlakukan demikian.

Berkaitan dengan remaja yang melakukan tindakan agresif dapat dijelaskan bahwa mereka secara umum dalam masa perkembangan. Di masa ini, usremaja akan terjadi banyak perubahan secara psikis. Pertama, keadaan emosi yang tidak stabil, sehingga menjadikan remaja memiliki emosi yang meledak-ledak. Kedua, perasaan menjadi sangat peka atau sensitive, sehingga menjadikan remaja mudah tersentuh dan tersinggung. Ketiga, sikap mental agresif yang ditunjukkan dalam bentuk suka menentang kepada aturan atau perintah, dan mulai mencari identitas diri. ${ }^{9}$ Perubahan 
psikis yang dilalui oleh remaja tentunya memiliki masalah yang mengiringi perubahan tersebut. Salah satu masalah yang menyertai perubahan psikis tersebut adalah ketidakmatangan intelektual dan emosional. Hal ini berakibat pada tindakan yang tidak rasional, cenderung emosional dan tanpa pikir panjang. ${ }^{10}$

Dengan adanya perubahan secara psikis menyebabkan adanya kecenderungan perilaku remaja kearah negatif. Menurut teori yang berkembang, remaja di Dusun Geger ini memiliki perilaku agresif sebagai berikut: ${ }^{11}$

1. Langsung-aktif-verbal, yaitu mencaci, mengumpat, dan memamerkan berlagak sebagaimana kebanyakan remaja.

2. Langsung-aktif-nonverbal, yaitu perilaku memukul, mendorong, dan serangan fisik lain.

3. Langsung-pasif-verbal, yaitu diam, tidak menghiraukan, cuek, dan acuh.

4. Tidak langsung-aktif-nonverbal, yaitu mencuri atau merusak barang orang lain, seperti yang dilakukan oleh remaja ketika berada di pondok pesantren.

\section{b. Pola Asuh Orang Tua dari Remaja di Desa Geger}

\section{Remaja AL yang diasuh oleh neneknya}

AL adalah remaja yang berusia sembilan belas tahun. Ia bersekolah di SMA berbasis pondok. AL masuk pondok pesantren atas perintah dari ibunya. Kedua orang tua AL telah bercerai sejak AL masih kecil. Ibunya menikah dan tinggal bersama suami barunya. AL tinggal dengan kakek dan neneknya. Nenek AL (KD) berusia tujuh puluh tahun, sedangkan kakeknya tujuh puluh lima tahun. Sejak dua tahun lalu kakeknya meninggal dunia, sehingga AL hanya tinggal bersama neneknya.. Dalam mengasuh KD tidak menuntut dan mengekang AL. Ia selalu memberikan nasehat dan petuah-petuah khususnya mengenai tata krama kepada orang yang lebih tua. KD juga menasehati $\mathrm{AL}$ supaya meminta izin ketika akan pulang terlambat. Hal tersebut dilakukan karena AL pernah pergi bermain dan terlambat pulang tanpa izin. Perilaku AL membuat KD sangat khawatir dan risau hingga mencari ke tetangga mengenai keberadaan AL.

Dalam mendidik AL, KD juga memberikan contoh langsung. KD memiliki rasa kepedulian kepada sesama dengan sangat gemar berbagi. Perilaku KD tersebut terlihat

\footnotetext{
10 Ibid.

${ }^{11}$ Agus Abdul Rahman, Psikologi Sosial, 207.
} 
oleh AL, sehingga AL memiliki sikap peduli, penyayang, dan amanah. Sikap sayang $\mathrm{KD}$ diajarkan secara modelling ketika AL akan masuk ke pondok pesantren. KD berusaha mempersiapkan kebutuhan AL selama di pondok. Berdasarkan ini terlihat bahwa AL hidup dengan penuh kasih sayang dari neneknya. Tidak ada peraturan yang mengikat AL ketika berada di rumah. AL sendiri bukan tipe anak yang suka bermain, selain itu kegiatan AL di rumah hampir teratur dengan sendirinya. Waktu untuk sholat dia pergi ke masjid, dan selebihnya dihabiskan di rumah untuk belajar atau membantu orang tua. Hal tersebut membuat KD percaya kepada AL. KD percaya AL akan terbuka menceritakan apapun yang terjadi. KD selalu menjadi pendengar yang baik dan memberikan respon ketika AL menceritakan apa yang dialami. KD juga tidak menuntut mengenai pilihan AL dan masa depannya. KD hanya ikut andil memberikan arahan agar menjadi lebih baik.

Terlihat KD menerapkan pola asuh demokratis yang memperlihatkan dan menghargai kebebasan yang tidak mutlak, dengan bimbingan yang penuh pengertian antara anak dan orang tua, memberikan penjelasan secara rasional dan objektif jika keinginan dan pendapat anak tidak sesuai. Baumrind mengatakan bahwa tipe pola asuh demokratis menyediakan lingkungan yang penuh kasih, melibatkan anak dalam pengambilan keputusan, dan memberikan kepercayaan untuk bersikap mandiri namun tetap terpantau. ${ }^{12}$ Fakta yang ditemui sesuai dengan teori yang menyampaikan bahwa dampak pola asuh demokratis diantaranya memiliki rasa bahagia, kontrol diri dan rasa percaya diri, mampu mengatasi stress, keinginan berprestasi dan komunikasi baik dengan teman maupun orang dewasa. ${ }^{13}$ Terlihat pola asuh yang diterapkan KD memberikan dampak positif atau baik terhadap perilaku AL. AL memiliki sikap peduli, ramah, memiliki kasih sayang terhadap sesama yaitu kepada teman sebaya, orang tua, maupun orang lain.

Meskipun AL dibesarkan bukan oleh keluarga lengkap, namun KD berhasil menciptakan suasana yang penuh kasih sayang. KD juga memberikan petuah dan membimbing kearah yang baik. Pola asuh yang dilakukan KD membuktikan bahwa pengasuhan keluarga sangat mempengaruhi perilaku anak. Selain membawa sisi

\footnotetext{
${ }^{12}$ Rahmatika Hamdani, "Pengaruh Tipe Pola Asuh Dan Penerimaan Sosial Terhadap Perilaku Merokok Pada Remaja Di Samarinda" Edukasi, 2 (Tb, 2019), 357.

${ }^{13}$ Puji Astutik, The Correlation Among The Type Of Care Pattern, The Parents' Education Level And The Status Of Children Under Five Nutrition. Jurnal Nomor 25 Volume 01 Desember Tahun 2014. 39.
} 
positif, pola asuh demokrasi juga membawa sisi negatif yaitu anak cenderung merongrong kewibawaan otoritas orang tua, karena segala hal harus dipertimbangkan oleh anak kepada orang tua. ${ }^{14}$ Sisi negatif tersebut semakin diperkuat oleh pengaruh lingkungan yang kurang baik. Setelah ditelaah lebih jauh ternyata AL juga memiliki perilaku agresif terhadap teman sebayanya. AL mengaku dirinya pernah menjadi salah satu korban dari perilaku agresif temannya. Perilaku dari temannya menyebabkan AL ikut meng-ghosob (mencuri) sandal dan menyakiti temannya. Hal tersebut hanya dilakukan AL ketika di pondok pesantren. Ketika berada di rumah, AL dikenal sangat baik budi pekertinya.

Dari fenomena yang ada menunjukkan lingkungan di luar keluarga juga berperan penting dalam membentuk perilaku anak. Penting bagi orang tua untuk mengontrol anak, meskipun sudah berusia remaja. Salah satu faktor penyebab munculnya perilaku agresif adalah perlakuan agresif yang diterima dari orang lain. Agus dalam bukunya mengatakan bahwa perilaku agresif muncul karena adanya motif eksternal dan juga hasil belajar. ${ }^{15}$ Hal tersebut juga dijelaskan oleh salah satu penelitian yang memuat mengenai dampak perilaku agresif. Dalam penelitian tersebut dikatakan bahwa salah satu dampak dari perilaku agresif adalah membuat korban berpotensi memiliki perilaku agresif. ${ }^{16}$ Kebenaran teori tersebut dapat dilihat melalui sebab timbulnya perilaku agresif pada diri AL.

\section{Remaja DV Yang Memiliki Orang Tua Religious}

DV merupakan anak pertama dari salah satu tokoh agama di Desa Geger. Ayah DV adalah seorang modin dusun yang sudah terkenal. Ayah DV bekerja sebagai modin dan petani. Ibunya adalah seorang ibu rumah tangga. DV dan keluarganya memiliki toko sembako yang tempatnya sedikit jauh dari tempat tinggalnya. DV memilih untuk bersekolah di sekolah berbasis pondok pesantren di Ponorogo. Saat ini DV berada di jenjang Madrasah Tsanawiyah (MTS) kelas tiga. Sesekali DV menyempatkan diri untuk berkunjung ke rumah. Ketika di rumah, DV membantu ibunya (SD) mengerjakan pekerjaan rumah dan mengasuh adiknya yang berusia tiga tahun.

\footnotetext{
${ }^{14}$ Siti Anisa, Kontribusi Pola Asuh Orang Tua terhadap Kemandirian Siswa Kelas II SMA Negeri 1 Balapulang Kabupaten Tegal Tahun Pelajaran 2004/2005. Skripsi Universitas Negeri Semarang:2005.

${ }_{15}$ Agus Abdul Rahman, Psikologi Sosial, 203.

$16 \mathrm{Tn}$, Kekerasan oleh anak, bentuk, penyebab, dampak, dan cara menanggulangi, https://health.kompas.com/read/2020/03/08/ di akses pada 16 Mei 2020
} 
Ketika DV sudah berada di pondok, orang tua hanya mengontrol perkembangan akademik anak dari rumah. SD sebagai orang tua memahami perannya sebagai orang tua. Dia memahami bagaimana seharusnya bersikap dan kapan waktu menempatkan dirinya sesuai apa yang seharusnya. Dia paham betul kapan dia harus menjadi sosok ibu, dan sosok teman. SD sadar bahwa orang tua memiliki tugas pengembangan akademik dan pembentukan perilaku atau tatakrama. Ketika berada di pondok, ternyata DV juga melakukan ghosob sandal dan juga berbicara kasar terhadap temannya. DV mengatakan bahwa dia melakukan perilaku agresif karena dia juga pernah menjadi korban perilaku agresif. Hal ini sebagai salah satu bukti bahwa perilaku agresif memungkinkan korban memiliki perilaku agresif juga. Selain itu, kasus ini juga memperlihatkan pengaruh yang sangat penting dari lingkungan dan pergulan. Ketika berada di rumah, orang tua berusaha mengerti apa yang dibutuhkan anaknya untuk mencapai perkembangan diri DV. Tentu saja sangat berbeda jauh dengan di pesantren dikarenakan jumlah santri yang cukup banyak. Sebagai orang tua yang tergolong masih muda, SD tidak mengekang DV sesuai dengan keinginan keluarga. SD menyadari betul bahwa remaja usia DV masih memerlukan banyak bimbingan, sehingga belum bisa sepenuhnya memahami kehidupan. SD mendukung keputusan anaknya ketika menyangkut hal baik.

Perihal sekolah, DV yang menentukan sendiri dia akan bersekolah dimana. Tugas SD adalah mencarikan informasi berkaitan dengan sekolah tersebut. SD memberikan kemungkinan-kemungkinan yang akan terjadi jika DV memilih di pondok pesantren. SD ingin menguji seberapa yakin DV dalam mengambil keputusan, sehingga dia dapat mempertanggung jawabkan keputusannya. SD memberikan penjelasan kepada DV bahwa jika sudah berada di pondok pesantren, dia tidak akan bertemu keluarganya lagi jika tidak dijenguk. Atmosfer lingkungan pondokpun juga berbeda dengan rumah sendiri, dan ketika membutuhkan sesuatu yang penting harus melalui telepon terlebih dahulu. DV memutuskan untuk masuk pesantren di usia tiga belas tahun bukan karena paksaan dari tua. Ia memilih pondok dengan tekat yang mantap di dalam hatinya untuk memperdalam ilmu agama. Orang tua melihat keputusan DV tersebut benar-benar telah dia pikirkan, maka orang tua berusaha membantu mencarikan informasi, memberikan dana, dan meluangkan waktu untuk menemani anaknya pergi ke pesantren. DV 
mendaftarkan dirinya sendiri melalui media online dan orang tua menemani saat mendaftar ke pesantren.

Dalam perihal management waktu, orang tua DV tidak memberikan peraturan secara ketat. Hanya peraturan terkait shalat yang diterapkan orang tua yaitu keharusan DV untuk melaksanakan sholat lima waktu tepat pada waktunya. Orang tua DV masih mentoleransi perilaku DV yang terkadang tidak mau membantu orang tua. Keluarga ini sangat mengutamakan masalah agama. Hal tersebut wajar mengingat orang tua DV adalah pemuka agama. Tanpa disadari aturan tersebut membuat anak menjadi lebih disiplin dan juga berani bertanggung jawab. SD sebagai orang tua juga mau meluangkan waktu untuk menjadi pendengar yang baik dari curahan hati anaknya. SD mampu menempatkan diri sebagai seorang ibu dan seorang teman.

DV yang diasuh oleh orang tua religious memberikan gambaran pola asuh yang Islami. Hal tersebut terlihat dari cara SD memberikan dukungan terhadap pilihan DV yang bersifat baik. SD juga membantu mencarikan apa yang dibutuhkan DV untuk mengembangkan diri. SD tidak mengekang apa yang ingin dilakukan anaknya selama bersifat positif, serta dia berusaha mengarahkan. Dalam hal peraturan, SD dan suaminya mengharuskan untuk sholat tepat waktu. SD juga mengetahui kapan dirinya harus berperan sebagai ibu dan kapan berperan sebagai teman. ${ }^{17}$ Dengan pola pengasuhan seperti yang digambarkan, DV memiliki sikap yang patuh terhadap orang tua, berani, bertanggung jawab, dan percaya diri dalam mengembangkan dirinya. ${ }^{18} \mathrm{Hal}$ ini sesuai dengan teori yang menjelaskan adanya pengaruh pola asuh terhadap perilaku remaja. Di samping perilaku baik, DV juga memiliki sikap agresif dikarenakan pernah menjadi korban perilaku agresif di pondok pesantren. Hal ini sejalan dengan yang disampaikan Agus dalam bukunya mengatakan bahwa perilaku agresif muncul karena adanya motif eksternal dan juga hasil belajar. ${ }^{19}$ Berdasarkan hal ini, selain cara mengasuh, lingkungan dan pergaulan remaja menjadi faktor penting yang juga harus diperhatikan.

\footnotetext{
${ }^{17}$ Rahmatika Hamdani, "Pengaruh Tipe Pola Asuh Dan Penerimaan Sosial Terhadap Perilaku Merokok Pada Remaja Di Samarinda" Edukasi, 2 (Tb, 2019), 356.

${ }^{18}$ Puji Astutik, The Correlation Among The Type Of Care Pattern, The Parents' Education Level And The Status Of Children Under Five Nutrition. Jurnal Nomor 25 Volume 01 Desember Tahun 2014. hal 39.

${ }^{19}$ Agus Abdul Rahman, Psikologi Sosial, 203.
} 


\section{Remaja HD dan orang tua hampir berusia lanjut}

HD adalah seorang remaja dari pasangan yang hampir berusia lanjut. HD merupakan anak tunggal dari ibu (SH) berusia 57 tahun dan ayah (SJ) 65 tahun. Orang tua HD bekerja sebagai seorang petani. Kondisi rumah HD begitu sederhana, temboknya dari batu bata, dan lantai rumah masih berupa tanah. Dengan kondisi keluarga seperti itu orangtua HD tetap bertekad menyekolahkan HD sampai jenjang terakhir. HD kini duduk di kelas satu Sekolah Menengah Kejuruan (SMK) di kabupaten Madiun. Sekolah HD memiliki stereotiype negatif yaitu siswa-siswinya banyak yang memiliki sikap tidak baik.

Dalam hal pengasuhan yang berbentuk perhatian atau kontroling, SH tidak mengekang dan melarang anaknya. HD lebih sering menghabiskan waktu di luar rumah dan SH membiarkannya, namun SH akan khawatir jika HD belum pulang. SH juga memberikan peluang kepada HD untuk mengembangkan dirinya melalui organisasi pencak silat. HD tidak melanjutkan pengembangan tersebut dikarenakan rasa malas. SH membiarkan keputusan HD untuk masuk dan kemudian keluar dari organisasi tersebut. Berdasarkan hal ini, dapat diketahui HD kurang memiliki rasa tanggung jawab. Selain kurang bertanggungjawab, HD juga memiliki sikap agresif. HD pernah membentak dan mengacuhkan perintah orang tuanya. Awalnya memang SH berusaha menutupi hal-hal negatif yang berkaitan dengan anaknya. Terlihat dari cara SH menjawab setiap pertanyaan dari peneliti. SH kebingungan menata kata yang tepat untuk menjawab pertanyaan, namun akhirnya dia mengakui meskipun tidak secara langsung. SH menganggap perilaku agresif HD sebagai hal yang wajar.

SH tidak menerapkan management waktu untuk HD. SH hanya melarang anaknya merokok sebelum memiliki pekerjaan. SH tidak menerapkan peraturan berkaitan dengan waktu bermain dan belajar. Meskipun tidak memberikan peraturan dalam bermain, SH memberikan nasehat agar HD menjadi lebih baik dengan adanya batasan-batasan bergaul. SH pernah menasehati HD berkaitan dengan waktu belajar, namun anaknya tidak mau menuruti. SH membiarkan HD untuk tidak belajar. SH menganggap kebanyakan anak laki-laki memang tidak mau belajar. Dia beranggapan bahwa apa yang akan terjadi pada anaknya sudah digariskan.

SH tidak mengekang keputusan anaknya untuk bersikap mandiri. HD memilih sendiri akan melanjutkan sekolah dimana. SH sudah memberikan arahan agar HD 
bersekolah di tempat lain, namun HD tetap bersikukuh ingin bersekolah di Sekolah Menengah Kejuruan (SMK) yang dipilihnya. HD beralasan teman-temannya berada disana. SH menyatakan sebenarnya ia bersedia mendengarkan cerita HD di sekolahnya, namun respon terhadap HD dirasa masih kurang. SH percaya bahwa nasib seseorang tidaklah sama. SH pun tidak mempermasalahkan anaknya menjadi seperti apa kedepannya. SH memasrahkan masa depan anaknya kepada sang pencipta.

Pola asuh yang diterapkan oleh SH dan suaminya dominan bersifat permisif. SH memiliki sikap pasrah terhadap apa yang anaknya lakukan dan apa yang diputuskan oleh Tuhan. Meskipun SH memberikan nasehat pada anaknya, namun rasa keibuannya yang lebih dominan membuatnya tidak tegas dalam menerapkan peraturan untuk HD. Terlihat bahwa SH tidak melakukan apa-apa ketika HD berperilaku kasar terhadap orang tua. ${ }^{20}$ Pola pengasuhan SH bersama suaminya memiliki pengaruh terhadap perilaku anak. HD memiliki perilaku yang kurang menghargai orang tua, bersikap acuh, dan kurang bertanggung jawab. HD juga memiliki nada bicara yang tinggi dengan siapa saja. HD juga sering menghabiskan waktunya di luar rumah. ${ }^{21}$ Selain dikarenakan pola pengasuhan yang cenderung permisif, lingkungan sekolah semakin memperkuat perilaku negatif HD apalagi sekolahnya memiliki stereotype yang buruk.

\section{Remaja RL yang diasuh oleh seorang ayah}

RL adalah remaja berusia empat belas tahun yang hanya diasuh oleh ayahnya. Ayahnya (MA) berusia 39 tahun dan ibunya FM berusia 35 tahun. MA bekerja sebagai tukang sayur yang berangkat jam empat pagi dan pulang jam tiga sore. FM bekerja sebagai asisten rumah tangga di luar negeri. MA memiliki perawakan tinggi sedikit kekar dan wajah yang tegas dengan tatapan yang tajam. MA bukanlah sosok yang galak atau kasar, tetapi dia memiliki sikap yang tegas.

Dalam merawat anaknya, MA mengaku tidak mengalami kesulitan. Hal tersebut dikarenakan RL merupakan anak yang patuh terhadap ayahnya. Meskipun mereka hanya bertemu beberapa jam saja dalam sehari, namun hubungan mereka tidak renggang. MA memberikan kebebasan anaknya untuk bergaul dan bermain dengan siapa dan kapan saja. Meskipun demikian MA tetap mengawasi dan mengontrol

${ }^{20}$ Rahmatika Hamdani, "Pengaruh Tipe Pola Asuh Dan Penerimaan Sosial Terhadap Perilaku Merokok Pada Remaja Di Samarinda" Edukasi, 2 (Tb, 2019), 356.

${ }^{21}$ Puji Astutik, The Correlation Among The Type Of Care Pattern, The Parents' Education Level And The Status Of Children Under Five Nutrition. Jurnal Nomor 25 Volume 01 Desember Tahun 2014. hal 39. 
perilaku RL dengan beberapa peraturan. RL menghabiskan waktunya dengan bermain dikarenakan di rumah tidak memiliki teman. RL pergi bermain sejak bangun tidur hingga akan tidur lagi. Akan tetapi pada jam-jam tertentu dia akan pulang untuk melaksanakan sholat. MA benar-benar mewajarkan perilaku RL yang sering bermain. MA memang tidak mengetahui sepenuhnya kegiatan RL. Dia memantau melalui telepon selular. Banyak yang mengatakan bahwa RL sering bermain dan tidak terurus oleh ayahnya, namun RL merupakan anak yang masih dikontrol dalam hal berperilaku. Hal ini terbukti, meskipun RL sering menghabiskan waktu bersama teman-temannya, ia memiliki perilaku yang patuh terhadap orang tuanya. RL langsung pulang ketika ayahnya memintanya pulang. MA juga sangat disiplin perihal sholat lima waktu, seperti yang dikatakan RL bahwa ayahnya pernah memarahinya karena terlambat sholat.

MA selalu memberikan kebutuhan RL, seperti pulsa dan uang jajan. Ketika RL meminta hal yang berbeda, MA akan menimbang terlebih dahulu. MA mencoba memenuhi kebutuhan pokoknya RL. Pemenuhan tersebut merupakan salah satu bukti bahwa MA sangat peduli dan sayang terhadap RL. Dengan sikap disiplinnya menunjukkan bahwa MA tidak sepenuhnya membiarkan RL. MA juga mewanti-wanti RL supaya hal buruk dari teman-temannya tidak ditirunya. MA juga menyempatkan waktu dengan RL untuk membahas masa depan RL. Hal tersebut menununjukkan kepedulian MA terhadap masa depan RL. Pilihan sekolah dan cita-cita RL bukan lagi kehendak dari MA selaku ayahnya. MA hanya memberikan arahan supaya RL menjadi lebih baik di masa depannya.

Berdasarkan data di atas diketahui bahwa pola asuh yang diterapkan MA adalah jenis pola asuh permisif-demokratis. Dimana pola ini mengadopsi dua jenis dalam penerapannya. Dikatakan permisif karena membiarkan RL untuk menghabiskan waktu bersama teman-temannya. Selain itu kebutuhan hidup RL dipenuhi, serta jarang menerapkan hukuman. Pola asuh MA ini menggambarkan seakan-akan RL tidak mendapat perhatian sama sekali. ${ }^{22}$ Dikatakan demokratis karena MA sangat peduli dengan RL. Hal ini terbukti dengan adanya peraturan yang ditetapkan oleh MA. Selain itu MA juga menyempatkan waktu untuk berbicara secara intens dengan RL dan

${ }^{22}$ Rahmatika Hamdani, "Pengaruh Tipe Pola Asuh Dan Penerimaan Sosial Terhadap Perilaku Merokok Pada Remaja Di Samarinda" Edukasi, 2 (Tb, 2019), 356. 
mengedepankan rasa disiplin dalam hal apapun. Pola asuh yang diterapkan orang tua bercirikan tidak mengekang, namun tetap terdapat peraturan di dalamnya. Memberikan kesempatan pada anak untuk berkembang dan lingkungan yang penuh cinta. ${ }^{23}$ Dari pola asuh yang demikian timbul perilaku negatif dan positif dalam diri RL. Perilaku negatif RL yaitu lebih banyak menghabiskan waktu di luar rumah, sehingga muncul anggapan bahwa RL adalah anak yang bandel. Kemudian perilaku positif RL adalah memiliki sikap disiplin dan patuh kepada orang tua. Kedisiplinan yang diterapkan MA ternyata mampu membentengi RL dari pengaruh teman-temannya.

\section{Remaja RK yang yang tinggal dengan keluarga besar}

RK adalah seorang remaja yang duduk di kelas dua tingkat menengah pertama. RK merupakan anak pertama dari dua saudara. Adik perempuannya masih berusia lima tahun. Dia tinggal bersama keluarganya lengkap dengan kakek dan nenek. Ibunya (SR) berusia 38 tahun dan sebagai ibu rumah tangga, dan ayahnya (AB) berusia 42 tahun bekerja sebagai wiraswasta. Sesekali nenek RK masih ikut bekerja sebagai rombongan ibu-ibu penanam padi di sawah orang. RK merupakan salah satu remaja yang gemar menghabiskan waktu di luar rumah bersama teman-temannya. Ketika RK belum pulang bermain SR akan mencari meskipun dengan berjalan kaki. SR juga akan memarahi RK karena terlambat pulang. Selain itu, pergaulan RK dengan temannya pun dibatasi. SR melarang $\mathrm{RK}$ bergaul dengan $\mathrm{RN}$, karena memang banyak orang mengetahui perilaku agresif RN terhadap orang tuanya. Dalam mengatur pergaulan RK, SR tidak hanya menasehati RK tetapi teman-teman yang berada di sekitar rumahnya pun ikut dinasehati.

RK memang banyak menghabiskan waktu bersama teman-temannya, namun SR menetapkan aturan waktu bermain RK. Aturan tersebut diberlakukan karena kepedulian SR kepada anaknya. Dia khawatir jika anaknya terlibat dengan pergaulan yang salah. Jadi selain membatasi waktu bermain, SR juga membatasi pergaulan anaknya. Sayangnya, peraturan yang dibuat hanya berlaku untuk masalah waktu bermain dan pergaulan saja. SR tidak menentukan waktu belajar. SR memasrahkan keputusan belajar pada diri RK. Pola yang diterapkan SR dalam mengasuh RK adalah tidak mengekang apa yang ingin dicapai oleh RK, namun SR juga menginginkan yang terbaik untuk anaknya. Maka dari itu, SR selalu memberikan nasehat perihal keputusan

${ }^{23}$ Ibid. 
RK. Salah satu arahan dan nasehat yang diberikan adalah perihal sekolah. SR menyarankan untuk sekolah di tempat yang terkenal baik, namun RK tidak mau. Selain itu, SR juga memasrahkan kepada RK mengenai cita-citanya setelah selesai menempuh pendidikan.

Jenis pola asuh yang diterapkan oleh SR dan suaminya dalam mengasuh RK adalah demokratif. Hal tersebut dapat dilihat melalui bentuk perilaku orang tua kepada anak, seperti memberikan waktu anak agar berkembang melalui lingkungan sosial, namun juga membatasinya. Sebagai orang tua SR berusaha memenuhi kebutuhan RK, namun tidak serta merta langsung diberikan. SR juga memberikan arahan dan nasehat kepada RK mengenai sekolah dan masa depannya. ${ }^{24}$ Dari hasil pengasuhan tersebut dapat dilihat bahwa perilaku RK lebih kearah positif. RK memiliki perilaku yang sopan terhadap orang lain dan ramah terhadap sesama. RK memang memiliki perilaku positif, namun dia juga memiliki perilaku agresif. SR mengakui bahwa RK memiliki watak yang keras. Hal ini diperkuat dengan penampilan wajah RK yang kelihatan tegas dan cuek.

\section{PENUTUP}

Pola asuh mempengaruhi pembentukan perilaku agresif remaja. Ada empat jenis perilaku agresif yaitu perilaku agresif langsung-aktif-verbal, langsung-aktif-non verbal, dan langsung-pasif- verbal, dan tidak langsung -aktif-nonverbal. Perilaku agresif yang berbeda berasal dari pola asuh yang berbeda. Selain pola asuh, faktor lingkungan juga mempengaruhi perilaku remaja.

Penelitian selanjutnya disarankan untuk lebih memperbanyak jumlah subyek dari berbagai macam latar belakang keluarga. Dianjurkan juga untuk menggali data lebih mendalam agar lebih lengkap, dan mampu mengungkap lebih banyak informasi tentang pola asuh dan perilaku remaja.

${ }^{24}$ Rahmatika Hamdani, "Pengaruh Tipe Pola Asuh Dan Penerimaan Sosial Terhadap Perilaku Merokok Pada Remaja Di Samarinda" Edukasi, 2 (Tb, 2019), 356. 


\section{DAFTAR RUJUKAN}

Anisa, Siti. Kontribusi Pola Asuh Orang Tua terhadap Kemandirian Siswa Kelas II SMA Negeri 1 Balapulang Kabupaten Tegal Tahun Pelajaran 2004/2005. Skripsi Universitas Negeri Semarang, 2005.

Arikunto, Suharsimi. Presedur Penelitian Suatu Pendekatan Praktik. Jakarta: Rineka Cipta, 2011.

Astutik, Puji. The Correlation Among The Type Of Care Pattern, The Parents' Education Level And The Status Of Children Under Five Nutrition. Jurnal Nomor 25 Volume 01 Desember Tahun 2014.

Hamdani, Rahmatika. Pengaruh Tipe Pola Asuh Dan Penerimaan Sosial Terhadap Perilaku Merokok Pada Remaja Di Samarinda. Jurnal penelitian Program Studi Psikologi, Fakultas Ilmu Sosial dan Ilmu Politik, Universitas Mulawarman (online). 2019. ejournal.psikologi.fisip-unmul.ac.id di akses pada 3 maret 2020.

Jannah, Miftahul. Remaja dan Tugas-Tugas Perkembangannya dalam Islam, Jurnal Psikoislamedia Volume 1, Nomor 1, April 2016 di akses pada 16 Mei 2020

Lestari, Sri. Psikologi Keluarga: Penanaman Nilai dan Penanganan Konflik dalam Keluarga. Jakarta: Kencana, 2012.

Munawir, M. Dampak perbedaan pola asuh terhadap perilaku agresif remaja di SMA Peraya. Jurnal Edukasi In Prosiding Seminar ASEAN: 2nd Psychology and Humanity, (Online). 2016. http://msi.umm.ac.id di akses pada 17 Maret 2020.

Rahman, Agus Abdul. Psikologi Sosial. Jakarta: PT Rajagrafindo Persada, 2017.

Sastriani, Anita. Keharmonisan Keluarga dan Pengaruhnya Terhadap Pengamalan Agama Anak di Gampong Beurawe Aceh. Skripsi: Universitas Islam Negeri ARRaniry Darussalam, Banda Aceh. 2018.

Setiowati, Erni Agustina dkk. Gambaran Agresivitas Anak dan Remaja di Area Beresiko, Jurnal Edukasi, (Online). 2017. http://jurnal.unissula.ac.id di akses pada 17 Maret 2020.

Tio, "Siswi SMP Bunuh Bocah 5 Tahun, Diduga Karena Kelalaian Orang Tua," dalam Kronologi, 9 Maret 2020. https://kronologi.id/2020/03/09/siswi-smp-bunuhbocah-5-tahun di akses pada 17 Maret 2020.

Tn. Kekerasan oleh anak bentuk penyebab dampak dan cara menanggulangi. https://health.kompas.com/read/2020/03/08/ di akses pada 16 Mei 2020.

Tn. "Memahami Perubahan Fisik dan Psikis Remaja". https://ghurubhaz.wordpress.com/2018/05/01/memahami-perubahan-fisik-dan-psikisremaja/di akses pada 16 Mei 2020.

Utami, Adristinindya Citra Nur dan Santoso Tri Raharjo. Pola Asuh Orang Tua Dan Kenakalan Remaja. Jurnal Pekerjaan Sosial, (Online), Vol. 2 No: 1. 2019. journal.unpad.ac.id di akses pada 3 maret 2020. 
Rosyada: Islamic Guidance and Counseling

Vol 2. No. 12021

Yusuf, Syamsu. Psikologi Perkembangan Anak dan Remaja. Bandung: PT. Remaja Rosdakarya, 2012. 